JOSETA: Journal of Socio Economic on Tropical Agriculture

Volume 1 Nomor 3: 57- 66 Desember (2019)

JOSETA: Journal of Socio Economic on Tropical Agriculture

http://ioseta.faperta.unand.ac.id

ISSN : 2686 - 0953 (Online)

\title{
Penguatan Kelembagaan Petani Terhadap Peningkatan Posisi Tawar Petani Gambir di Nagari Koto Lamo Kecamatan Kapur Ix Kabupaten 50 Kota
}

\section{Strengthening Farmer Institutionts Towards Increasing The Bargaining Position Of Gambier Farmers In Nagari Koto Lamo, Kapur Ix Sub-District, 50 Cities District}

\author{
Nela Novita ${ }^{1}$ Yonariza $^{2}$, Sri Wahyuni ${ }^{3}$ \\ ${ }^{1}$ Mahasiswa Program Studi Agribisnis Fakultas Pertanian Universitas Andalas, Padang \\ ${ }^{2}$ Staff Pengajar Program Studi Agribisnis Fakultas Pertanian Universitas Andalas, Padang \\ ${ }^{3}$ Staff Pengajar Program Studi Agribisnis Fakultas Pertanian Universitas Andalas, Padang \\ E-mail Korespondensi: nelanovita2809@gmail.com \\ Received: 30th Oktober, 2019; 1st Revision: 2thNovermber, 2019; Accepted: 12thDesember, 2019
}

\begin{abstract}
Abstrak
Penelitian ini bertujuan : (1) Mendeskripsikan kondisi pemasaran gambir di Nagari Koto Lamo Kecamatan Kapur IX Kabupaten 50 Kota. (2) Menyusun upaya penguatan kelembagaan yang dilakukan untuk meningkatkan posisi tawar petani gambir di Nagari Koto Lamo Kecamatan Kapur IX Kabupaten 50 Kota. Penelitian ini dilakukan pada tanggal 05 Agustus sampai 05 September 2019. Metode yang digunakan adalah metode survei. Populasi dalam penelitian ini berjumlah 107 petani. Jumlah petani sampel yang diambil adalah sebanyak 30 orang yang ditentukan dengan metode proporsional random sampling. Cara pengambilan sampel dengan metode simple random sampling. Sedangkan untuk pengambilan sampel pedagang dengan metode snowball sampling. Analisis data yang digunakan ialah analisi deskriptif kualitatif dan kuantitatif. Hasil penelitian menunjukkan bahwa petani di Nagari Koto Lamo mayoritas menjual gambir ke pedagang pengumpul yang ada hubungan keluarga dengannya, fungsi pemasaran yang membedakan petani dan pedagang pengumpul adalah fungsi informasi pasar, hanya dilakukan oleh pedagang pengumpul sehingga harga gambir dikendalikan oleh pedagang pengumpul. Sistem pembayaran yang dilakukan oleh pedagang pengumpul kepada petani adalah secara tunai. Marjin pemasaran antara petani dengan pedagang pengumpul sebesar Rp 4.000/Kg. Upaya penguatan kelembagaan petani melalui pemberdayaan tidak mengikat petani dan pedagang pengumpul. Aturan dalam pemasaran gambir juga tidak ada yang menguntungkan petani.
\end{abstract}

Kata Kunci: Penguatan Kelembagaan Petani, Petani Gambir, Pemasaran gambir, dan Posisi Tawar Petani

\section{Abstract}

This study aims : (1) To describe the condition of gambier marketing di Nagari Koto Lamo Lamo, Kapur IX Sub District, 50 Cities District (2) Develop institutional strengthening efforts undertaken to improve the bargaining position of gambier farmers in Nagari Koto Lamo, Kapur IX Sub District, 50 Cities District. This research was conducted on August 5 to September 5 2019. The method used was a survey method. The population in this study amounted 107 farmers. The number of sample farmers taken was 30 people determined by the proportional random sampling ethod. How to take samples by simple random sampling method. Where as for sampling tradesr with 
snowball sampling method. Analysis of the data used is qualitative and quantitative descriptive analysis. The results showed that the majority of farmers in Nagari Koto Lamo sell gambier to collectors who are related family, the marketing function that distinguishes farmers and collectors is the market information function, only carried out by collecting traders so that the price of gambier is controlled by the collecting traders. The payment system for collectors to farmers is in cash. Marketing margin between farmers and collectors is Rp 4.000/Kg. Efforts to strengthen farmer institutions through empowerment do not bind farmers and collectors. There are no rules for gambier marketing that benefit farmers.

Keywords : Strengthening Farmer's Institutions, Gambier's Farmer, Gambier marketing, and Farmers Bargaining Positions

\section{PENDAHULUAN}

Pertanian merupakan sektor yang sangat penting dalam perekonomian nasional. Sejalan dengan tahapan-tahapan perkembangan ekonomi maka kegiatan jasa dan bisnis yang berbasis pertanian juga akan meningkat, yaitu kegiatan agribisnis akan menjadi salah satu kegiatan unggulan pembangunan ekonomi nasional dalam berbagai aspek yang luas (Saragih, 2010). Salah satu sektor pertanian yang sangat berpengaruh terhadap perekonomian masyarakat Indonesia adalah sektor perkebunan. Perkebunan telah memberikan pengaruh berbagai sendi kehidupan di beberapa masyarakat Indonesia dari sosial budaya, politik dan lingkungan. Komoditi perkebunan yang penting salah satunya adalah gambir (Uncaria gambier Roxb). Tanaman gambir merupakan tanaman perdu, termasuk salah satu diantara Rubiace (kopikopian), memiliki nilai ekonomi yang tinggi, yaitu dari ekstrak (getah) daun dan ranting mengandung asam katechu tannat, katechin, pyrocatecol, florisin, lilin, fixed oil. Gambir merupakan komoditi yang memiliki volume dan nilai ekspor yang tinggi . Tanaman gambir merupakan komoditi unggulan Sumatera Barat. Produksi dan luas lahan terbesar adalah di Kabupaten 50 Kota.

Komoditi gambir sangat memerlukan pasar. Agar pasar berfungsi dengan baik dan dapat menciptakan keuntungan, diperlukan kelembagaan yang kuat melalui aturan main yang jelas. Aturan main yang jelas untuk penegasan norma tingkah laku kelompok-kelompok yang bertransaksi, guna mengurangi biaya transaksi tinggi. Biaya transaksi tinggi terjadi karena ketidaksetaraan informasi di pasar.

Menurut Dimyati (2007) permasalahan yang masih melekat pada sosok petani dan kelembagaan petani di Indonesia adalah : peran dan fungsi kelembagaan petani sebagai wadah organisasi petani belum berjalan secara optimal.

Nagari Koto Lamo merupakan salah satu nagari di Kecamatan Kapur IX yang merupakan penghasil gambir terbesar di Kabupaten 50 Kota (BPS Kabupaten 50 Kota, 2010). Di Nagari Koto Lamo, ada petani yang membentuk kelompok dan ada juga yang tidak. Akan tetapi, kelompok yang dibentuk tidak sesuai dengan yang diharapkan. Tidak ada kegiatan yang dilakukan untuk menunjang usahatani masing-masing anggota kelompok. Kelompok dibentuk hanya untuk menerima bantuan dari pemerintah, seperti subsidi pupuk, bibit tanaman jagung, dan lain-lain. Setelah menerima bantuan, anggota kelompok bahkan tidak pernah berkumpul lagi.

Petani di Nagari Koto Lamo menjual gambir ke pedagang pengumpul di pasar gambir secara sendiri-sendiri. Harga gambir ditetapkan oleh pedagang pengumpul, sedangkan petani hanya sebagai penerima harga (price taker) dan tidak bisa meningkatkan posisi tawarnya. Oleh karena itu, perlu penguatan kelembagaan petani agar harga tidak bisa dikendalikan oleh pedagang pengumpul dan masingmasing pelaku dalam pemasaran gambir mendapatkan keuntungan yang sewajarnya.

Dari permasalahan diatas, maka muncul pertanyaan sebagai berikut :

1. Bagaimana kondisi pemasaran gambir di Nagari Koto Lamo Kecamatan Kapur IX Kabupaten 50 Kota?

2. Bagaimana upaya penguatan kelembagaan yang dilakukan untuk meningkatkan posisi tawar petani gambir di Nagari Koto Lamo Kecamatan Kapur IX Kabupaten 50 Kota. 
Berdasarkan uraian diatas, maka peneliti perlu melakukan suatu penelitian yang berjudul "Penguatan Kelembagaan Petani terhadap Peningkatan Posisi Tawar Petani Gambir di Nagari Koto Lamo Kecamatan Kapur IX Kabupaten 50 Kota".

\section{METODE PENELITIAN}

Penelitian ini dilakukan di Nagari Koto Lamo Kecamatan Kapur IX Kabupaten 50 Kota. Penentuan daerah penelitian dilakukan dengan metode purposive atau sengaja. Metode yang digunakan dalam penelitian ini adalah metode survei. Jenis penelitian yang dilakukan adalah penelitian deskriptif. Tujuan dari penelitian deskriptif adalah untuk membuat deskripsi, gambaran atau lukisan secara sistematis, faktual dan aktual mengenai fakta-fakta, sifat-sifat serta hubungan antar fenomena yang diselidiki baik mengenai status kelompok manusia, suatu objek, suatu set kondisi, suatu sistem pemikiran, ataupun suatu kelas peristiwa pada masa sekarang (Nazir, 2009:54. ). Metode pengambilan sampel petani adalah dengan proporsional random sampling. Sedangkan pengambilan sampel pedagang dengan menggunakan metode snowball sampling.

Data yang dikumpulkan dalam penelitian ini adalah data primer dan data sekunder. Data primer diperoleh dari sumber (sampel) melalui wawancara dengan menggunakan kuesioner yang telah dipersiapkan serta melakukan pengamatan langsung di lapangan. Data sekunder adalah data yang diperoleh data yang diperoleh dari instansi seperti Badan Pusat Statistik, Kantor Wali Nagari Koto Lamo, serta literatur-literatur yang berhubungan dengan penelitian ini. Berdasarkan tujuan penelitian, maka variabel yang diamati adalah :

Tujuan pertama untuk mendeskripsikan kondisi pemasaran gambir di Nagari Koto Lamo, maka variabel yang diamati yaitu lembaga pemasaran, fungsi pemasaran, saluran pemasaran, sistem penetapan harga, sistem pembayaran, analisis biaya dan marjin pemasaran.

Tujuan kedua yaitu menyusun upaya penguatan kelembagaan yang dilakukan untuk meningkatkan posisi tawar petani gambir, maka variabel yang digunakan adalah :

1. Pemberdayaan petani, dengan indikator :

a) Kolektifikasi modal

b) Kolektifikasi produksi

c) Kolektifikasi dalam pemasaran

2. Aturan main, dengan indikator :

a) Jenis aturan main

b) Individu yang terikat

c) Ketaatan terhadap aturan

Untuk menjawab pertanyaan pertama, yaitu mendeskripsikan kondisi pemasaran gambir di Nagari Koto Lamo Kecamatan Kapur IX dilakukan analisis deskriptif kualitatif dan kuantitaif untuk biaya dan marjin pemasaran. Untuk menjawab pertanyaan kedua yaitu menyusun upaya penguatan kelembagaan yang dilakukan untuk meningkatkan posisi tawar petani gambir, dilakukan analisis deskriptif kualitatif.

\section{HASIL DAN PEMBAHASAN}

\section{A. Gambaran Umum Daerah Penelitian}

Nagari koto Lamo merupakan salah satu nagari yang berada di Kecamatan Kapur IX Kabupaten 50 Kota yang memiliki luas 103,36 $\mathrm{Km}^{2}$. Adapun batas-batas Nagari Koto Lamo yaitu sebelah Utara berbatasan dengan Muaro Paiti, Koto Bangun, Durian Tinggi, sebelah Selatan berbatasan dengan Kecamatan Bukit Barisan, Sebelah Barat berbatasan dengan Sialang, dan sebelah Timur berbatasan Lubuak Alai dan Kecamatan Pangkalan.

Nagari Koto Lamo terdiri dari 5 jorong, yaitu : Jorong Koto Tuo, Jorong Koto Tangah, Jorong Tanjuang Bungo, Jorong Sungai Nyanyiang dan Jorong Lolo. Untuk aspek kependudukan, Nagari Koto 
Lamo memiliki jumlah total penduduk 2.938 jiwa, yang terdiri dari 1.527 jiwa laki-laki dan 1.411 jiwa perempuan. Secara umum kondisi perekonomian masyarakat Nagari Koto Lamo tergantung pada sektor perkebunan. Mayoritas terdiri dari petani gambir, dan beberapa orang sebagai petani karet dan petani sawah. Selain dibidang pertanian dan perkebunan, masyarakat Nagari Koto Lamo juga ada yang bekerja sebagai pedagang, tukang kayu dan lain-lain.

\section{B. Kondisi Pemasaran Gambir} a) Lembaga Pemasaran

Di Nagari Koto Lamo, lembaga pemasaran gambir yang ada yaitu pedagang pengumpul. Petani menjual gambir ke pedagang pengumpul di pasar gambir sesuai dengan hari pasar di jorong masingmasing. Pedagang pengumpul di Nagari Koto Lamo menjual gambir yang dibeli dari petani ke pedagang besar di Kota Padang. Peran pedagang pengumpul ini tentu saja sangat penting dalam pemasaran gambir, karena mereka merupakan lembaga pemasaran yang membeli gambir mendistribusikan gambir sehingga sampai di tangan konsumen ataupun eskportir.

Petani tidak bisa menjual gambirnya sendiri ke konsumen, karena akan mengeluarkan biaya yang besar. Selain itu, petani juga tidak memiliki informasi atau link untuk menjual gambirnya. Oleh karena itu, dibutuhkan lembaga perantara untuk menyalurkan gambir hingga sampai ke konsumen sesuai dengan pendapat. Di Nagari Koto Lamo lembaga perantara gambir yaitu pedagang pengumpul, karena pedagang pengumpul langsung menjual gambir ke pedagang besar di Kota Padang. Jarak Nagari Koto Lamo cukup jauh dari Kota Padang, sekitar 7 jam perjalanan, sehingga petani lebih memilih menjual gambir ke pedagang pengumpul, sesuai dengan pendapat Hidayati (2000) yang mengemukakan bahwa jasa lembaga pemasaran sangat diperlukan dalam proses pemasaran, karena jauhnya jarak tempat produksi dengan konsumsi.

Pedagang pengumpul lokal yang membeli gambir ke petani di daerah penelitian ada 3 orang, yaitu Musliadi, Rudianto dan Rusmanto. Petani yang menjual gambir ke Musliadi adalah sebanyak 7 orang, ke Rudianto 9 orang dan ke Rusmanto 14 orang. Petani menjual gambir ke pedagang dengan alasan yang berbeda-beda. Ada yang menjual gambir ke pedagang dengan alasan hubungan keluarga, karena langganan tetap, dan ada juga alasan lain seperti ingin mencoba menjual ke pedagang yang berbeda. Petani yang menjual gambir kepada pedagang yang ada hubungan keluarga dengannya adalah sebanyak 11 orang, 10 orang dengan alasan lain (ingin mencoba menjual ke pedagang yang berbeda, berteman dengan pedagang, dan lain-lain), dan dengan alasan langganan tetap kepada pedagang sebanyak 9 orang. Petani yang berlangganan tetap ini dikarenakan petani merasa percaya dan senang bertransaksi dengan pedagang tersebut.

\section{b) Fungsi Pemasaran}

Lembaga-lembaga yang terlibat dalam pemasaran gambir di Nagari Koto Lamo adalah petani dan pedagang pengumpul. Lembaga pemasaran melakukan fungsi pemasaran masing-masing.

Fungsi-fungsi pemasaran yang dilakukan oleh lembaga-lembaga pemasaran gambir di lokasi penelitian sebagai berikut :

\section{Fungsi Pemasaran yang Dilakukan oleh Petani}

Fungsi pemasaran yang dilakukan oleh petani adalah:

a. Fungsi pertukaran yang dilakukan oleh petani berupa kegiatan penjualan, sedangkan untuk pembelian tidak ada karena petani bertindak sebagai produsen.

b. Fungsi fisik yang dilakukan petani adalah fungsi pengolahan, pengangkutan, penyimpanan, dan pengemasan.

c. Fungsi fasilitas yang dilakukan petani berupa fungsi resiko dan modal.

\section{Fungsi Pemasaran yang Dilakukan oleh Pedagang Pengumpul}

Fungsi pemasaran yang dilakukan oleh pedagang pengumpul adalah: 
a. Fungsi pertukaran yang dilakukan pedagang pengumpul berupa pembelian dan penjualan.

b. Fungsi distribusi fisik yang dilakukan pedagang pengumpul berupa pengolahan, pengangkutan, penyimpanan dan pengemasan.

c. Fungsi fasilitas yang dilakukan pedagang pengumpul berupa penanggungan resiko, modal, informasi pasar.

Fungsi pemasaran yang tidak dilakukan oleh petani adalah fungsi pembelian karena petani adalah sebagai produsen. Selain itu, petani juga tidak melakukan sortasi dan informasi pasar yang termasuk dalam fungsi fasilitas. Sedangkan fungsi pemasaran yang tidak dilakukan oleh pedagang pengumpul yaitu fungsi sortasi. Kegiatan sortasi biasanya dilakukan oleh pedagang besar dan eksportir.

\section{c) Saluran Pemasaran}

Saluran distribusi untuk suatu barang adalah saluran yang digunakan oleh produsen untuk menyalurkan barang tersebut dari produsen ke konsumen atau pemakai industri. Saluran pemasaran gambir yang ada di Nagari Koto Lamo, yaitu :

Petani $\rightarrow$ Pedagang Pengumpul $\rightarrow$ Pedagang Besar/Eksportir $\rightarrow$ Konsumen

Petani membutuhkan pedagang pengumpul untuk menyalurkan gambir ke pedagang besar hingga akhirnya sampai ke eksportir atau konsumen. Petani tidak bisa langsung menjual gambir ke pedagang besar/eksportir dikarenakan membutuhkan biaya yang besar, sedangkan modal petani hanya cukup untuk melakukan usahataninya. Selain itu, pedagang pengumpul yang menjual gambir ke pedagang biasanya bagian dari kaki tangan pedagang besar. Pedagang besar menetapkan aturan tertentu untuk mengikat pedagang pengumpul ataupun lembaga pemasaran lain dibawahnya, sehingga lembaga pemasaran dibawah bisa dikendalikannya. Sesuai dengan penelitian Nasution, Amelia Haris (2015) tentang kelembagaan dalam pengolahan dan pemasaran gambir mengatakan posisi pedagang besar yang menjadi kaki tangan eksportir dan membuka peluang adanya kolusi antara pedagang besar dengan eksportir juga berdampak pada posisi pedagang pengumpul dan penyalur yang juga menjadi kaki tangan lembaga pemasaran diatasnya sehingga menyebabkan lemahnya posisi tawar petani dalam pemasaran gambir.

\section{d) Sistem Penetapan Harga}

Berdasarkan sistem penetapan harga, harga gambir di Nagari Koto Lamo ditetapkan oleh pedagang pengumpul, petani hanya sebagai penerima harga (price taker). Hal ini dikarenakan petani tidak memiliki akses dan informasi pasar. Petani hanya mendapat informasi mengenai harga gambir dari petani lain yang lebih dulu menjual gambirnya dan dari pedagang pengumpul. Petani tidak mengetahui apakah informasi yang diterima dari pedagang pengumpul itu benar atau tidak, karena tidak adanya sumber informasi selain itu. Hal ini sesuai dengan pendapat Sesbany (2008) lemahnya posisi tawar petani umumnya disebabkan petani kurang memiliki akses pasar, informasi dan permodalan yang memadai.

Petani di daerah penelitian memiliki modal yang cukup untuk usahataninya, tetapi sangat kurang memiliki akses dan informasi pasar yang membuat petani tidak berdaya dalam melakukan negosiasi harga dengan pedagang pengumpul. Informasi harga gambir hanya diperoleh dari petani yang lebih dulu menjual gambirnya dan dari pedagang pengumpul. Hal ini juga sejalan dengan penelitian Nasution, Amelia Haris (2015) tentang kelembagaan dalam pengolahan dan pemasaran gambir yaitu besarnya akses informasi harga yang dimiliki kelembagaan pemasaran menyebabkan petani hanya mampu menerima harga yang ditetapkan oleh lembaga pemasaran.

\section{e) Sistem Pembayaran Gambir}

Berdasarkan sistem pembayaran, pedagang pengumpul (toke) di Nagari Koto Lamo membayar ke petani secara tunai, kecuali pedagang pengumpul sedang mengalami keadaan yang sulit seperti kondisi pemasaran gambirnya kurang berjalan dengan lancar, maka pembayaran akan dilakukan secara tidak tunai atau berangsur-angsur kepada petani. Jika pembayaran tidak dilakukan secara tunai, biasanya akan ada perjanjian antara pedagang pengumpul dengan petani, misalnya kepastian tentang waktu pelunasan kepada petani. Biasanya pedagang pengumpul selalu menepati janjinya. 
Pembayaran tunai diterima oleh petani yang tidak memiliki pinjaman kepada pedagang. Di Nagari Koto Lamo, mayoritas petani gambir menggunakan modal sendiri, tidak ada yang meminjam modal kepada pedagang pengumpul sehingga sistem pembayaran yang dilakukan oleh pedagang pengumpul kepada petani secara tunai. Selain itu, tidak ada keharusan petani untuk menjual kepada siapa, karena tidak ada yang mengikatnya.

\section{f) Analisis Biaya dan Marjin Pemasaran}

Analisis biaya pemasaran gambir di Nagari Koto Lamo dilakukan dari petani sampai ke pedagang pengumpul. Sedangkan analisis marjin pemasaran adalah menganalisis harga yang diterima oleh konsumen dikurangi dengan harga yang diterima oleh petani petani produsen. Analisis marjin pemasaran gambir yang dilakukan pada penelitian ini adalah hanya sampai ke pedagang pengumpul yang ada di Nagari Koto Lamo.Untuk mengetahui biaya dan marjin pemasaran gambir di Nagari Koto Lamo dapat dilihat padal tabel 2 dibawah ini.

Biaya pemasaran yang dikeluarkan petani adalah sebesar Rp 1.674,98/Kg.. Sedangkan biaya pemasaran yang dikeluarkan oleh pedagang pengumpul adalah sebesar Rp 1.217,52/Kg Ini menunjukkan bahwa biaya pemasaran petani lebih besar daripada biaya pemasaran pedagang pengumpul walaupun lebih banyak unsur-unsur biaya pemasaran pedagang pengumpul. Hal ini dikarenakan adanya potong kadar air pada petani yang nilainya cukup besar.

Keuntungan pedagang pengumpul adalah sebesar Rp $2.782,48 / \mathrm{Kg}$. Jumlah ini terbilang cukup besar, karena keuntungan pedagang pengumpul lebih dari dua kali lipat biaya pemasaran yang dikeluarkannya. Harga jual pedagang pengumpul adalah sebesar Rp 27.333,33/Kg sehingga didapat marjin pemasaran pedagang pengumpul sebesar $\mathrm{Rp} 4000 / \mathrm{Kg}$. Sedangkan marjin pemasaran petani adalah nol rupiah. Hal ini mengindikasikan bahwa terdapat selisih harga jual gambir yang cukup jauh antara petani dan pedagang pengumpul, sehingga pedagang pengumpul memperoleh keuntungan yang cukup besar dalam pemasaran gambir.

Tabel 1. Analisis Biaya dan Marjin Pemasaran

\begin{tabular}{lcc}
\hline Uraian & $\begin{array}{c}\text { Harga } \\
(\mathbf{R p} / \mathbf{K g})\end{array}$ & $\begin{array}{c}\text { Biaya } \\
(\mathbf{R p} / \mathbf{K g})\end{array}$ \\
\hline Petani & $23.466,67$ & \\
\hline a. Harga Jual & & 104,53 \\
\hline b. Biaya Pemasaran & 73,78 \\
\hline$\quad$ Biaya Pengemasan & $1.496,67$ \\
\hline$\quad$ - Biaya Transportasi & $1.674,98$ \\
\hline$\quad$ Potal Biaya & $21.791,69$ & \\
\hline c. Penjualan Bersih & - & \\
\hline d. Marjin Pemasaran Petani & 376,94 \\
\hline Pedagang Pengumpul & $23.333,33$ & 55,31 \\
\hline a. Harga Beli & 714,16 \\
\hline b. Biaya Pemasaran $\quad$ Biaya Penjemuran & 71,11 \\
\hline$\quad$ Biaya Pengemasan & $1.217,52$ \\
\hline$\quad$ Biaya Transportasi & $2.782,48$ \\
\hline$\quad$ Biaya Bongkar Muat & $4.000,00$ \\
\hline$\quad$ Total Biaya & \\
\hline c. Keuntungan & \\
\hline d. Marjin Pemasaran Pedagang Pengumpul & $\mathbf{2 . 8 9 2 , 5 0}$ \\
\hline e. Harga Jual & \\
\hline Total Biaya Pemasaran & \\
\hline
\end{tabular}




\begin{tabular}{lc}
\hline Total Keuntungan Pemasaran & $2.782,48$ \\
\hline Total Marjin Pemasaran & 4.000 \\
\hline
\end{tabular}

Total biaya pemasaran gambir di Nagari Koto Lamo yaitu biaya yang dikelurkan petani ditambahkan dengan biaya yang dikeluarkan pedagang pengumpul yaitu sebesar $\mathrm{Rp} 2.892,50 / \mathrm{Kg}$. Total keuntungan sebesar Rp 2.782,48/Kg. Sedangkan total marjin pemasaran gambir adalah sebesar Rp $4.000 / \mathrm{Kg}$, sama dengan marjin pemasaran pedagang pengumpul karena nilai marjin pemasara petani adalah nol rupiah.

\section{Penguatan Kelembagaan 1. Pemberdayaan Petani}

Pemberdayaan petani adalah peningkatan kemampuan petani sehingga petani bisa lebih mandiri dan tidak tergantung kepada pihak lain. Petani gambir tidak bisa melakukan pemberdayaan untuk dirinya sendiri. Bentuk pemberdayaan petani di Nagari Koto Lamo yaitu adanya penyuluhan dari lembaga penyuluhan pertanian dari tingkat kecamatan. Akan tetapi, kegiatan penyuluhan tersebut sangat jarang dilakukan..

Pemberdayaan petani juga bisa dilakukan melalui kelompok tani. Petani di Nagari Koto Lamo ada yang berkelompok, tetapi kelompok tersebut tidak aktif melakukan kegiatan apapun yang dapat menunjang usahatani mereka. Kelompok tani petani gambir yang terbentuk di Nagari Koto Lamo dibentuk sebagai formalitas dan wadah mendapatkan bantuan atau subsidi dari pemerintah. Bantuan tersebut bisa berupa pupuk, bibit jagung, dan lain-lain. Anggota kelompok juga banyak yang merasa kecewa karena ternyata bantuan tersebut tidak sampai ke tangan mereka, hanya ketua kelompok yang mendapatkannya, selebihnya didapatkan oleh oknum-oknum tertentu seperti lembaga pertanian di tingkat kecamatan yang bekerjasama dengan ketua kelompok.

\section{a. Kolektifikasi Modal}

Kolektifikasi modal yaitu mengumpulkan modal secara berkelompok. Kolektifikasi modal merupakan salah satu bentuk upaya penguatan kelembagaan petani untuk membantu meningkatkan posisi tawar petani. Modal yang terkumpul ini bisa dimanfaatkan oleh petani untuk usahatani mereka. Akan tetapi, petani gambir di Nagari Koto Lamo hanya sedikit yang membentuk kelompok. Petani gambir yang memiliki kelompok adalah sebanyak 13 orang, sedangkan sebanyak 17 orang tidak memiliki berkelompok. Di Nagari Koto Lamo tidak ada petani yang menyimpan modal secara kolektif.

Kolektifikasi modal juga bisa dilakukan melalui Koperasi Unit Desa (KUD). KUD bisa dimanfaatkan sebagai lembaga keuangan tempat simpan pinjam oleh petani. Jika petani mengalami kesulitan dalam permodalan saat akan melakukan usahatani, bisa melakukan peminjaman kepada koperasi. Sedangkan untuk petani yang memiliki modal yang berlebih, bisa disimpan di koperasi. Hal ini tentu saja sangat membantu petani, karena pasti ada saatnya petani mengalami krisis keuangan. Akan tetapi, di Nagari Koto Lamo tidak ada KUD. Dulu ada rencana dari masyarakat untuk membentuk KUD, tetapi belum terlaksanakan sampai sekarang.

\section{b. Kolektifikasi Produksi}

Kolektifikasi produksi yaitu merencanakan produksi secara berkelompok. Petani gambir tidak bisa melakukan panen usahataninya sendiri. Di Nagari Koto Lamo, petani mengerjakan usahatani (mangampo) bersama dengan petani lain yang disebut anak kampo. Anak kampo ini biasanya terdiri dari dua sampai tiga orang dan dipimpin oleh nodo yang biasanya adalah pemilik lahan. Nodo ini juga termasuk ke dalam anak kampo. Nodo bersama anak kampo akan merencanakan terlebih dahulu mengenai produksi gambir. Perencanaan ini bisa berupa penentuan jenis gambir yang akan dibuat, kuantitas, dan pembagian tugas untuk masing-masing pekerja (anak kampo).

Anak kampo diberi upah sebesar Rp 500.000 per orang setiap minggu. Anak kampo yang terbentuk ini hanya ada sampai masa kampo habis, atau sampai lahan gambir langkeh. Jika lahan gambir sudah 
langkeh, maka anak kampo akan ikut mangampo dengan petani lain. Jadi, setiap masa kampo, anak kampo yang terbentuk akan berbeda-beda orangnya.

Di Nagari Koto Lamo, mayoritas mata pencaharian masyarakat di Nagari adalah sebagai petani gambir, oleh karena itu seluruh petani gambir mengatakan jika mereka bekerja di lahannya sendiri, maka mereka akan berperan sebagai nodo. Tidak ada yang membiarkan anak kampo bertindak sebagai nodo.

\section{c. Kolektifikasi Pemasaran}

Kolektifikasi pemasaran yaitu menjual hasil usahatani secara berkelompok, agar volume gambir yang dijual lebih besar dan biaya yang dikeluarkan lebih sedikit. Petani gambir di Nagari Koto Lamo menjual gambirnya secara sendiri-sendiri, tidak ada yang berkelompok. Adapun yang membantu hanyalah anak kampo yang turut serta mengangkut gambir ke pasar. Hal ini dapat menjadikan pedagang pengumpul menetapkan harga gambir secara sepihak dan petani hanya sebagai penerima harga (price taker). Petani di lokasi penelitian tidak ingin saling bekerjasama satu sama lain. Hal ini juga dikarenakan tidak ada yang berperan sebagai penggerak, sehingga petani lebih memilih bersifat individualis dan hanya memikirkan kepentingan mereka masing-masing.

Kolektifikasi pemasaran juga bisa dilakukan melalui Koperasi Unit Desa (KUD). Sedangkan di Nagari Koto Lamo tidak ada KUD. Jika ada koperasi, maka bisa menjadi penghubung antara petani gambir dengan pedagang besar atau eksportir, sehingga harga yang diterima tidak jauh berbeda dengan harga dari pedagang besar. Selain itu, koperasi juga bisa dimanfaatkan untuk menyimpan gambir apabila harga gambir mengalami penurunan atau sangat rendah. Akan tetapi, pada kenyataannya petani tetap memilih menjual gambir ke pedagang pengumpul karena uang yang diterima lebih cepat.. .

\section{Norma dan Aturan Main dalam Pemasaran Gambir}

\section{a. Jenis Aturan Main}

Aturan main dalam pemasaran gambir sangat diperlukan, baik untuk petani maupun untuk pedagang pengumpul. Hal ini dilakukan agar transaksi jual beli gambir bisa berjalan dengan lancar. Aturan main yang ada di Nagari Koto Lamo dalam pemasaran gambir salah satunya adalah aturan nagari untuk petani gambir, yaitu iuran petani. Bentuk aturannya yaitu jika gambir yang dijual beratnya lebih dari $60 \mathrm{~kg}$, maka harus memberi iuran sebesar 1 kilogram gambir. Biasanya iuran tersebut digunakan untuk keperluan mesjid, bantuan untuk petani yang mendapatkan kemalangan seperti lahannya kebakaran, dan lain-lain.

Aturan nagari lainnya yaitu transaksi jual beli gambir harus dilakukan di kios gambir, tidak boleh dirumah petani, rumah pedagang, maupun di lahan gambir. Sedangkan aturan dari pedagang pengumpul untuk petani yaitu jika gambir yang dijual masih tinggi kandungan airnya, maka harganya akan dikurangi. Untuk petani yang meminjam modal ke pedagang pengumpul, gambirnya harus dijual ke pedagang tersebut, tidak boleh dijual ke pedagang lain.

Aturan dan kesepakatan antara petani dengan pedagang pengumpul atas dasar saling percaya. Selain itu, juga ada aturan dari pedagang pengumpul untuk petani. Jika gambir yang dijual masih tinggi kandungan airnya, maka hitungan beratnya akan dikurangi beberapa kilogram. Sampai sekarang, belum ada aturan pemerintah yang menguntungkan petani. Hal ini tentu saja merugikan petani, dimana petani yang selalu menjadi korban atas ketidakadilan harga. Yang bisa diharapkan adalah kebijakan dari pemerintah daerah yang bisa membantu petani, misalnya dengan membuat Badan Usaha Milik Nagari (BUMNAG). Di Nagari Koto Lamo telah ada BUMNAG, tetapi belum berjalan sesuai dengan yang diinginkan.

Peran pemerintah sangat diharapkan untuk membuat kebijakan dalam pemasaran gambir. Kebijakan ini salah satunya bisa dilakukan dengan cara menetapkan harga jual minimal gambir, membuat lembaga pusat informasi mengenai harga gambir di Sumatera Barat dan membentuk BUMN atau BUMD yang membeli gambir dari petani, sehingga petani tidak perlu khawatir kemana gambirnya akan dijual. 


\section{a. Individu yang Terikat}

Individu yang terikat dengan aturan iuran petani sebesar $1 \mathrm{~kg}$ setiap $60 \mathrm{~kg}$ adalah petani gambir dengan pemerintah nagari/jorong. Sedangkan aturan nagari tentang menjual gambir di kios gambir mengikat petani dan pedagang pengumpul. Walaupun cukup memberatkan bagi petani, karena petani yang akan mengangkut gambir dari rumah ke pasar. Jika pedagang pengumpul membeli ke rumah petani, maka petani tidak perlu mengeluarkan biaya dan tenaga untuk melakukan pengangkutan. Walaupun demikian, menjual gambir di kios gambir tidak terlalu mempengaruhi kenaikan posisi tawar petani, mengingat harga gambir yang dijual petani sekarang sangat rendah.

\section{b. Ketaatan terhadap Aturan}

Sejauh ini, petani di daerah penelitian tidak ada yang melanggar aturan nagari dalam pemasaran gambir, karena iuran petani dalam bentuk gambir $1 \mathrm{~kg}$ langsung diserahkan oleh toke yang membeli gambir petani ke perangkat nagari/jorong. Sedangkan aturan dari pedagang pengumpul tentang kadar air pada gambir masih sering dilanggar oleh petani. Hal ini dikarenakan banyak petani yang membutuhkan uang secepatnya, sehingga gambir yang baru di produksi beberapa hari sebelum hari pasar tetap dijual tanpa ditunggu kering terlebih dahulu. Karena masih banyak petani yang melakukan hal tersebut, sehingga pedagang pengumpul akan mengurangi harga gambir sesuai banyaknya kandungan air yang ada.

\section{KESIMPULAN}

\section{A. Kesimpulan}

1. Petani di Nagari Koto Lamo mayoritas menjual gambir ke pedagang pengumpul yang ada hubungan keluarga dengannya. Fungsi pemasaran dilakukan oleh petani dan pedagang pengumpul. Yang membedakannya adalah fungsi informasi pasar, hanya dilakukan oleh pedagang pengumpul sehingga harga gambir dikendalikan oleh pedagang pengumpul. Sistem pembayaran yang dilakukan oleh pedagang pengumpul kepada petani adalah secara tunai. Marjin pemasaran antara petani dengan pedagang pengumpul adalah sebesar Rp 4.000/Kg.

2. Upaya penguatan kelembagaan petani melalui kolektifikasi modal, kolektifikasi produksi dan kolektifikasi pemasaran tidak mengikat petani dan pedagang pengumpul di Nagari Koto Lamo. Begitu juga dengan aturan dalam pemasaran gambir di Nagari Koto Lamo, tidak ada yang menguntungkan petani.

\section{B. Saran}

1. Perlu adanya pengaktifan Badan Usaha Milik Nagari (BUMNAG) agar petani bisa menyimpan gambir saat harga gambir rendah dan pedagang pengumpul tidak bisa mengendalikan harga gambir.

2. Diharapkan untuk kedepannya tidak terdapat lagi marjin pemasaran yang besar antara petani dan pedagang pengumpul.

3. Pemerintah daerah seharusnya membuat kebijakan dalam pemasaran gambir yang juga bersifat mengikat pedagang pengumpul.

\section{DAFTAR PUSTAKA}

Dimyati, A. 2007. Pembinaan Petani dan Kelembagaan Petani. Balai Penelitian Tanaman Jeruk dan Buah Subtropika Tlekung-Batu. Jawa Timur.

Hidayati, A. 2000. Analisis Kinerja Sistem Pemasaran dan Lembaga Penunjang Pemasaran Kaitannya dengan Pengembangan Produksi Rumput Laut [Tesis]. Bogor : Program Pascasarjana, Institut Pertanian Bogor.

Nasrul, Wedy. 2012. Pengembangan Kelembagaan Pertanian untuk Peningkatan Kapasitas Petani terhadap Pembangunan Pertanian. Jurnal Menara Ilmu Vol. III No. 29, Juni 2012. 
Nasution, Amelira Haris. 2015. Peran Kelembagaan Dalam Pengolahan dan Pemasaran Gambir di Kabupaten Lima Puluh Kota [Tesis]. Institut Pertanian Bogor.

Nazir, Moh. 2009. Metode Penelitian. Bogor: Ghalia Indonesia.

Putri, Suriani. 2017. Analisis Faktor-Faktor Yang Mempengaruhi Kekuatan Tawar Petani Gambir Di Kenagarian Siguntur Tua Kabupaten Pesisir Selatan Sumatera Barat [Skripsi]. Padang : Universitas Andalas.

Saragih, Eliyas Sebastian. 2010. Pertanian Organik. Depok, Indonesia Penebar Swadaya.

Sesbany, 2008. Penguatan Kelembagaan Petani untuk Meningkatkan Posisi Tawar Petani [Skripsi]. STTP Medan. 